\title{
Study on Marxism Faith of Contemporary College Students
}

\author{
Dongshan Feng \\ Huanghe Science \&Technology College \\ Zhengzhou City of He’nan Province 450006
}

\begin{abstract}
There appear many problems of Marxism faith among contemporary college students. In terms of internal issues, utilitarian and realistic of faith are critical. In external matters, belief diversification and blind following are obvious conflicts. Above mentioned problems will affect construction of socialist ideology, and also have a key impact on college students of setting their outlook on life, world and values in a correct way. Thus, it's essential for us to start from problems to find out fundamental reasons. It's necessary to conduct pragmatic Marxism faith education in colleges and universities through the national mainstream ideology environment resist western ideology measures, guide college students to have rational faith choice perspective to build an effective way for college students' Marxism faith.
\end{abstract}

Keywords-College Students; Ideological; Political belief; Marxism

\section{INTRODUCTION}

Belief refers that people believe in and respect a certain value ideal in an extreme way. Belief is also unwavering faith and pursuit for self-life value object in spiritual life. It also can be regarded a kind of transcending beyond self-life, and a code of conduct. It is a basic attitude to distinguish what to do and not do with much care[1].

Political beliefs mean citizen show his value identity of given political forms and ultimate solicitude to politics. Political belief reflects a political rationality and comfort, which is psychological basis of a specific political form. The psychological basis is the fundamental requirement of political stability and development. Political beliefs deal with relationships between men and society and balance civil interests to build self-esteem, satisfied, fair, free and equal society. Political beliefs have value orientation and provide citizens with clear political goals.

Marxist belief is the only correct political belief for university students in China. It has been proved by practice, so far the greatest, and the most energetic, most perspective scientific belief in human history. It is the basic idea for China to found and govern the country. In the process of socialist revolution and construction, it fully shows its validity and creativeness. Therefore we must adhere to this right faith; otherwise you will lose theoretical and practical foundation of regime. It is emotional resonance produced by deep cognition of Marxism in China's political environment, and comprehensive cognitive system which is consistent with cognitive behavior tendency.

Explore of College Students' faith in Marxism, in modern society, we must survey on College Students' current situation of Marxist faith, and analyze University Students' belief in Marxism alienation of reason. Furthermore, put forward effective approach to the construction of university students' belief in Marxism.

\section{Current Situation And Problems of College STUDENTS' MARXISM FAITH}

The institute conducted a questionnaire survey for college students' Marxism faith, with 1000 questionnaires, recovery of 987 questionnaires and 947 valid questionnaires. Questionnaires involve the view concerning on Marxism, socialism with Chinese characteristics, direction of selfpolitical belief, the communist party of China, motivation of joining party(if has the intentions), understanding of ideological competition, as well as Marxism faith education, etc.

We can analyze from results that mainstream of college students' Marxism faith is positive, healthy and upward. Students' Marxism faith cognition is extensive and realistic on practice level. Regarding to cultivation of the students' belief in Marxism, $77 \%$ of college students think that teachers play a key role of positive publicity.

Problems can be presented that college students' Marxism faith also faces two contradictions, ideology diversification and Marxist belief adherence unification, indifference of citizens in daily life of ideology and pluralistic civil society value judgment. In terms of value pursuit faith, college students are products of two contradictions, which present three standard problems, namely pursuit of power ranking, pursuit of material standard, intention to pursue transcendence of God, looking for solace in religion. Students' Marxism faith appears blurred, and some college students don't know the real essence of Marxism with hesitation in front of Marxism belief. From theory to practice, number of college students with true beliefs is reducing. Marxist belief among college students suffers a crisis. 


\section{College Students' MarXism Faith Problems REASONS ANALYSIS}

College students' Marxism faith problems are due to state, society, colleges and universities.

\section{A. Objective Reasons of Social Existence}

First of all, Marxism popularity is not so high. Under influence of a variety of factors, public can not adhere to guidance of Marxism in a correct way. Society is filled with one-sided dogma understanding of Marxism theory. Reflective and individual crisis results in mass crisis of Marxism belief crisis. College students are vulnerable to infection.

Second, side effects caused by market economy. Market economy attaches great importance to interests, and enterprise and individual always try to pursue self-interest maximization, which leads to self-benefiting view. It is the weakening cause of college students' Marxism faith. They mainly focus on the economy, neglect shaping of spiritual life, and lose value rational recognition of socialist ideology.

Again, social economy made great achievements while political and cultural system reform still lag behind, which result in gaps in political and cultural institution. Social and economic transformation change class power, new class has been generated and way of production data has been changed, which makes private, private owner, freelancers have more social influence than before to gradually become a strong social group. Their ideological situation influenced the college students' belief[2]. Social economic transition brought sufficiency of social ethics and social norms, inner conflict between modern science and traditional authority value belief, confrontation between material value and spiritual value, contradiction between rational value and tools. There appears corruption, fraud and employment difficulties, inadequate protection, unfair distribution, etc. The country fails to respond in time, thus results in economic and moral, traditional political and constitutional politics contradictions. It also affects college students in choosing political beliefs. College students' beliefs are in dissimilation.

Fourth, there is still lack of transformation and recognition of outstanding traditional culture innovation environment. Integration of traditional cultural spirit and Marxism has not been promoted. Traditional humanistic spirit destroyed belief cultivation foundations. Values which tend to utilitarian lead to the weakening of Marxist faith. Multiple values and concepts fade mainstream ideology impact. Before you begin to format your paper, first write and save the content as a separate text file. Keep your text and graphic files separate until after the text has been formatted and styled. Do not use hard tabs, and limit use of hard returns to only one return at the end of a paragraph. Do not add any kind of pagination anywhere in the paper. Do not number text heads-the template will do that for you.

\section{B. Marxist belief education in colleges and universities lacks scientific and effective methods.}

First of all, ideological and political education in colleges and universities of traditional ideology, focus on the political functions of Marxism belief with limitation of Marxist philosophy, as well as little attention, reflection and criticism of the social contradictions and problems in the transition period. Thus make Marxist belief education lack of appeal, and weakening of traditional mainstream ideology of the students. There exist historical reasons such as lack of understanding of Marxism, and also its own insufficient humanities accomplishment, as well as intolerance understanding of Marxist philosophy.

Secondly, college education adopts comprehensive administration, thus campus culture tend to be utilitarian and diversification with less attention to college students' humanistic education. It makes multicultural values be filled with campus, which not only causes suspicion to the mainstream ideology, but also make students follow blindly to other pseudoscience cultural values. As legal persons, colleges and universities have dissatisfied Marxist belief education effect. The common problems can be indicated as follows: understanding of Marxism lacks depth and breadth; blindly cater to all kinds of social ideological trend; fade political dominance of ideological and political education for college students. Above reasons lead college students' believes in a wrong way with worldly and utilitarian tendency. Marxist belief has been marginalized and complicated. Socialism, such as dedication, collectivism and serving people gradually disappears among students.

Again, some political teachers do not stand firmly to Marxist political. Marxist beliefs of teachers will affect the choice of students' beliefs. If there is no inner belief of Marxism in teachers' practice of life, students will be absolutely affected[3]. Some teachers have weak Marxist theory background and philosophical accomplishment with outdated education concept. They may lack of theory with practice ability. They can just constantly repeat what the book says, and interpret Marxist with theories. There is no good communication between teachers and students, thus Marxist belief education effect is not qualified.

\section{Invasion of West Peaceful Evolution (from socialism back to capitalism )}

The evolution and infiltration of economic globalization and capitalist ideology has a long history. As early as in 1992, before Clinton has not become President of the United States, he said: One day China will be on the same path of Eastern Europe and the former Soviet Union communist regimes, and the United States must do everything he can to encourage this process. Peaceful evolution way will become the main route of western socialism overturn. Fukuyama has commented in his book of "End of History" that democratic system of western countries may be" the end "of the development of human ideology," the last rule human form ", thus results in the "end of history". On one hand, western countries promote the ideology of capitalism by the end of so-called ideology. Also, they are trying to adopt economic globalization to fade ideology. In the end, they can use western ideology to dominate the world. The ideological battle is in silence.

Penetration of western ideology to our country will not cease. Universities are the best breakthrough for western 
powers peaceful evolution. Western powers will infiltrate all kinds of strong western ideological trends into universities with various flexible methods. Assisted with new media, western culture and ideology appears like undercurrent surging in the college. Some college students get lost in the middle of various ideas and issues. In addition to lack of effective means of Marxist belief education in colleges and universities, college students object to empty preaching of Marxist belief education. They seem more interested in so-called "new ideas", which make a easy way to peaceful evolution.

\section{College Students Own Subjective Reasons}

College students' main body consciousness has been enhanced.” What's faith", "Have faith or not" "how to believe in faith" and so on should be started from the ego needs, not based on social needs. Self-worth choice of "What I want" becomes the mainstream. It makes college students' belief began to change, from abandon authority to extreme advocate personal value. Pursuit of personal goals gradually becomes instrumentalization.

First of all, college students' group characteristics and growth environment influence the formation of right belief. Students groups have active thoughts, innovative ideas, selfindependence, thoughts based on perceptual experience. They are not mature enough with mental instability, lack of rational thinking, weak correct judgment ability, lack of ability to resist setback, and "self-organization" among students. These all affect college students' Marxism faith. New media has a huge impact on the students, and it's covered by multivariate information, multi-dimensional perspective, and all kinds of good and bad intermingled trend of convergence: religious ideas and feudal superstition, individualism, hedonism, money worship ideas, etc. In addition that cultural construction social environment in the area of is weak, college students' belief becomes multivariate and alienated, and even have a weakening faith on Marxist.

Second, college students still lack Marxism theory accomplishment, and have shallow understanding of Marxism. They fail to grasp Marxism from an overall view and recognize the development of Marxism. Many contradictions caused by social changes during the transitional period of the western cultural diversity, negative effects in real life, perceptual utilitarian cognitive style, lead to misjudgment of Marxism. College students' self-care and interests standard appeal dislocates with Marxist historical view. They have doubt about Marxism values, such as communism, spirit of serving people, which led to alienation of faith of Marxism.

\section{EFFeCtive Ways to Foster College StUdents' MARXISM FAITH}

According to problems of Marxist belief, we should take effective measures to reconstruct effective path of Marxist ideological identity of college students.

\section{A. Construction of Marxist Ideology Environment}

First of all, construction of Marx's mainstream ideology is the basis of the college students' Marxism faith education. Whether online or offline, we should take the initiative to dominate ideological field. We should adopt Internet to carry forward the positive energy and restrain negative effect on society. We should actively promote Marxist faith to be available in life and be normalized. Promote Marxism more in public society. As a philosophical belief, its faith goal is social practice - the communist society. It is social status with rich materials, developed economy and adequate spirit. The state is necessary to further take advantage of institutional arrangements to strengthen citizen Marxist ideological education. We must adhere to three confidences, strengthen efforts to fight corruption and promote social justice, promote people's livelihood, purify social atmosphere, and advocate socialist core values. By doing so, we can build a green civilization with political civilization, social integrity, citizens noble characters.

Second, countries should strengthen Marxist theory innovation research by common and practical methods. Thus it can express innovation theory in popular, simple and philosophical way. We should integrate popularization and classic reading, and give full consideration to life and practice of the Marxism. Popular readers should be promoted for different stages and levels to launch a public full cognitive learning. Explain the long history of Marxism to make social citizen including college students ally understand the Marxist essence.

\section{B. Strategies to deal with penetration of Western ideology}

Firstly, the science of Marxism and revolutionary should be fully recognized. The practice of China's socialist revolution and construction accounts for the truth of Marxism. Try to be confident in our own choice and give full play to the farreaching influence of Marxist Philosophy on the Marxist beliefs of university students. Evert Marxist Philosophy such as the thought of world materiality and everything starting from the reality, the rule of everything has universal connection and systematic thinking approach, the eternal development of things and those conflicting views, the unity of theory and practice, and so on has the value of truthfulness, which has benefits on the creating Marxism culture, impacting on the wind direction of social consciousness, thus taking the role of resisting Western ideology.

Secondly, college students should insist on the nationality as to Marxist faith education, highlighting the times. On the one hand, excavating the educational resources of traditional beliefs, such as the thoughts of taking the world as on community and taking the people as the foundation of the state; learning the communication ways of traditional folk culture such as folk art, famous pulpit, family precepts and people regulation to spread Marxism concept. On the other hand, keep pace with times, highlight the times, and develop Marxism in creativity, trying to surpass Marxism.

Thirdly, the establishment of the college students' Marxist faith should have a long-term and basic countermeasures, needing to have a clear reorganization for the peaceful evolution of the Western ideology and strengthening the leading position of the Marxist ideology[4]. Through some specific social activities, promote students to develop their Marxism practical abilities, and thus the cultivation of students' 
Marxism belief should become the basic task of college education. Take specific strategic responses to create harmonious social environment for the building of Marxism faith, thus forming healthy cultural atmosphere.

\section{The ways of developing Marxism BeliefEducation in universities}

In the process of forming college students' Marxist faith, the high education has the most significant role, and the education of Marxist Belief in colleges and universities is very important.

Firstly, construct the atmosphere of Marxist beliefs in colleges and universities.

Build the educational atmosphere of Marxism popularization in colleges and universities. The leaders should attach importance to the advancement of Marxist faith education, make the Marxist faith education throughout schooling education, take it as the foundation of Marxist faith education, and make the Marxist propaganda education as the basis of colleges and universities. In addition, focus on the party's education policy and control the positive aspects of public opinions in colleges and universities, and get hold of the mainstream socialist ideology from the aspects such as school management, students education, as well as various community activities, and so on.

Second, highlight ideological and political lesson as a role of main channel of Marxist belief education.

We should give full play to positional function of ideological and political lesson to make education college students have a rational understanding that socialism is superior to capitalism. We should continue improvement and innovation of college students' Marxism faith education ways and methods. In the process of education, we should get rid of teaching materials of Marxism and propaganda of Marxism education pattern. Instead of explaining theories with theories and explain truths with truths, we should integrate theory with practice. Combination of theory and practice is inherent requirement of Marxism with Chinese characters and time tendency and also the best way to examine the effects of education.

It's key to build a group of high quality education teachers for Marxism faith education. Marxism theory accomplishment and loyalty of political education in colleges and universities teachers are related to sincerity and effect of education. If a teacher has psychological resistance for Marxism, he will have negative effects on college students. Universities should continuously focus on education quality cultivation and promotion of teachers.

In terms of teaching content, except compulsory course, Marxist-Leninist classics reading class should be taught in colleges and universities. Develop college students' humanities accomplishment. Make greater efforts to support from fund, propaganda, atmosphere and so on to give a comprehensive institutional arrangement. Colleges and universities must strengthen research on Marxism and develop innovative Marx's works and books. Combine political and public, confess faith of political ideology, and strengthen importance and difficulty of Marxist ideological work through history.

Educational levels. Ideological and political education still has a lot of space to improve. In Marxist belief education, we should fully exploit strong power displayed in the social practice, combining with the case of Marxism characters to analyzed Marxism truth value vividly. Combine rationality and irrationality, and combine reasoning persuasion and emotion. Educational reform achievements "Teaching Reform and Construction in a comprehensive exploration way based on effectiveness of Introduction" of Professor Gu Yumin in Fudan University won second prize among National Educational Reform, which is a push to thought and political lesson teaching reform.

Again, make full use of community, network to participate in political practice and promote Marxist faith cultivation.

Colleges and universities should set up Marxist classics study group out of class, and actively carry out the second classroom of Marxist education to make college student have their own understanding and to Marxism truth. For example, M.M Learning Institute of Jilin University (Marxism-Leninism and Mao Zedong Thought Research Institute). It was established in 1989, and has developed more than 20000 members till right now with good result.

Youth League Committee in colleges and universities should make full use of network platform and take the initiative to lead network position of Marxism. We should use new media to develop college students' Marxism faith education. Make more efforts to Youth Maxims Education Training project to promote college students' education normalization.

Colleges and universities should strengthen social practice of Marxist study. Political participation is an important dimension of cultivating college students' Marxism faith. Actively use community to create opportunities for college students on campus and off-campus political participation. Guide students to participate in political activities in a rational, legal and orderly way.

\section{Marxist faith construction of college students on their own.}

First of all, college students should take Marxist philosophy as a kind of self-accomplishment, so it will be more favorable to the recognition and understanding of Marxism. Mr. Feng Youlan argues that Philosophy is system reflection of life, and reflection result is philosophy. As a practical philosophy, it points to society with target of communist society. As college students, for their own development, they need to have a philosophy accomplishment. Marxist philosophy can be used as guide college students' faith - realization of communism society.

Second, college students' cognition and understanding of Marxist philosophy should be desanctify and demonize, which should be brought to scientific cognition. Marxist philosophy is a milestone in the history of western philosophy. Bertrand Russell wrote in the western philosophy, Marx "He claimed socialism to be scientific socialism.", "He is a Renaissance of materialism, add new explanation to materialism and make 
connected to human history." "He believes that all the dialectical movement in some kind of impersonal sense is progress, and he must think that if socialism is built, it brings more happiness feudalism and capitalism." It is obvious that Marxism is a philosophical belief for practice in social life. College students should increase the philosophy accomplishment; increase their ability to comparative analysis and scientific understanding of Marxist life.

\section{CONCLUSION}

The cultivation of contemporary university students' belief in Marxism is a systems engineering, all out efforts are from the country, the society, the school, the family and the personal. We depend on theoretical study and practical training; we must construct a set of effective and feasible measures to promote the university students' belief in Marxism.

\section{REFERENCES}

[1] Wang Xuejian, Li Dongpo. Outstanding Problems and Countermeasures of College Students Belief Education [J] Thought Education Research, 2010 (11).

[2] Zhou Xi. Problems and Its Cause of Marxist Belief in Contemporary University Students [J] School Party Construction and Ideological Education, 2013 (12).

[3] Zheng Min. College Students' Marxism Faith Attitude Causes and Countermeasures Study [J] Hubei Social Sciences, 2014 (5).

[4] Mei Ping, Lin Xiao. Research Review of Contemporary Chinese University Students Belief Problem [J] Modern University Education, 2009 (6). 